\title{
Estrus expression and pregnancy rates in heifers primiparous and multiparous Nelore cows subjected to timed artificial insemination with strategic use of gonadotropin-releasing hormone
}

\section{Expressão de estro e taxas de prenhez em novilhas, primíparas e multíparas Nelore submetidas à inseminação artificial em tempo fixo com uso estratégico de hormônio liberador de gonadotrofina}

\author{
Denis Vinicius Bonato ${ }^{1}$; Luigi Carrer Filho2; Eriko Silva Santos'; \\ Murilo Rezende Figueira²; Marcela Bortoletto Cerezetti; Fábio Morotti4; \\ Marcelo Marcondes Seneda ${ }^{5 *}$
}

\section{Highlights}

The primiparous females had a lower rate of estrus.

No difference in the pregnancy rate among the three categories of those in estrus.

No difference in pregnancy for females that did not manifest estrus and received GnRH.

\section{Abstract}

We evaluated the effects of nulliparous, primiparous, and multiparous conditions on the estrus and pregnancy rates in females that did not show estrus but were treated with gonadotropin-releasing hormone $(\mathrm{GnRH})$ at the time of timed artificial insemination (TAl). Nelore females $(n=531)$ were allocated according to the following categories: nulliparous $(n=144)$, primiparous $(n=132)$, and multiparous $(n=255)$. The animals received a conventional TAI protocol, and estrus expression was identified by the absence of paint in the sacrococcygeal region on the day of TAl. Females that did not show estrus were treated with $10 \mu \mathrm{g}$ of $\mathrm{GnRH}$ together with insemination. The rates of estrus and pregnancy were analyzed using a logistic regression

1 Prof. Dr., Postgraduate Program in Animal Science with Emphasis on Bioactive Products, Universidade Paranaense, UNIPAR, Umuarama, PR, Brazil. E-mail: denisbonato@prof.unipar.br

2 Veterinarian, Neopecuária Genetics na Bovine Reproduction Company, NEOPECUARIA, Londrina, PR, Brazil. E-mail: luigi@camposecarrer.com.br; eriko@camposecarrer.com.br; murilo@camposecarrer.com.br

${ }^{3}$ PhD Student in Animal Bioscience, Universidade Estadual de São Paulo, USP, Pirassununga, SP, Brazil. E-mail: macercela.cerezetti@usp.br

4 Prof. Dr., Laboratory of Animal Reproduction and Professional Master in Veterinary Clinics, Universidade Estadual de Londrina, UEL, Londrina, PR, Brazil. E-mail: fabiomorotti@uel.br

${ }_{5}$ Prof. Dr., Laboratory of Animal Reproduction and Animal Science Program, UEL, Londrina, PR, Brazil. E-mail: marcelo. seneda@uel.br

* Author for correspondence

Received: June 06, 2021 - Approved: Sept. 06, 2021 
model $(P<0.05)$. The estrus expression was lower $(P=0.006)$ in the primiparous $(61.36 \%)$ group than in the nulliparous (76.39\%) and multiparous $(75.69 \%)$ groups. Similar pregnancy rates were observed in females that showed estrus (nulliparous $84.54 \%$, primiparous $86.42 \%$, and multiparous $80.31 \% ; P=0.39$ ) and in females that did not show estrus and received GnRH (nulliparous $41.18 \%$, primiparous $56.86 \%$, and multiparous 58.06\%; $P=0.24)$. The total pregnancy rates were also similar $(P=0.98)$ among the categories (nulliparous $74.3 \%$, primiparous $75.0 \%$, and multiparous $74.9 \%$ ). The primiparous females had a lower rate of estrus, and the pregnancy rates were similar among the categories that received $\mathrm{GnRH}$.

Key words: Breeding biotechnology. Category. Cattle. Conception. Ovulation.

\section{Resumo}

O objetivo do trabalho foi avaliar o efeito das categorias nulíparas, primíparas e multíparas sobre a taxa de manifestação de estro e a taxa de prenhez de fêmeas que não manifestaram estro, mas foram tratadas com GnRH no momento da inseminação artificial em tempo-fixo (IATF). Foram utilizadas 531 matrizes, todas da raça Nelore, alocadas de acordo com a categoria: nulíparas $(n=144)$, primíparas $(n=132)$ e multíparas ( $n$ = 255). As matrizes foram submetidas a um protocolo reprodutivo para inseminação artificial em tempofixo (IATF) e tiveram a expressão do estro identificada pela ausência de tinta na região sacrococcígea no dia da inseminação. As fêmeas que não apresentaram estro receberam $10 \mu \mathrm{g}$ de $\mathrm{GnRH}$ no momento que foram inseminadas. As taxas de estro e prenhez foram analisadas por meio de um modelo de regressão logística $(P<0,05)$. A expressão do estro foi menor $(P=0,006)$ no grupo de primíparas $(61,36 \%)$ do que nos grupos de nulíparas (76,39\%) e multíparas (75,69\%). Taxas de prenhez semelhantes foram observadas em fêmeas que apresentaram estro (nulíparas $84,54 \%$, primíparas $86,42 \%$ e multíparas $80,31 \%$; $P=0,39$ ) e em fêmeas que não apresentaram estro e receberam GnRH (nulíparas 41,18\%, primíparas 56,86\% e multíparas $58,06 \% ; P=0,24)$. As taxas de prenhez total também foram semelhantes $(P=0,98)$ entre as categorias (nulíparas 74,3\%, primíparas 75,0\% e multíparas 74,9\%). As fêmeas primíparas apresentaram menor taxa de estro e as taxas de prenhez foram semelhantes entre as categorias que receberam $\mathrm{GnRH}$.

Palavras-chave: Biotecnologia de melhoramento. Categoria. Concepção. Gado. Ovulação.

\section{Introduction}

Timed artificial insemination (TAl) is a widespread technique with well-established hormonal protocols and proven results (Baruselli, Ferreira, Sá, \& Bó, 2018). However, the advancement of the economic viability associated with sustainability still requires an improvement in production rates (Florindo, Medeiros Florindo, Talamini, Costa, \& Ruviaro, 2017; Rosa et al., 2019). The progress of knowledge of TAl has allowed the adaptation of protocols, thereby resulting in better rates
(Baruselli et al., 2018). Thus, several studies have aimed to generate information that can help to increase TAI pregnancy rates (Ferreira et al., 2018; Gouvêa et al., 2018; Pfeifer et al., 2015).

The relationship between pregnancy rates and estrus expression was evaluated in Nelore females subjected to TAI (Nogueira et al., 2019). The authors found that the pregnancy rate of animals that show estrus is $20.91 \%$ higher than that of cows that do not express estrus. Cows that do not show estrus during TAI usually do not respond adequately 
to the protocol and do not have a dominant follicle of adequate size to produce sufficient estrogen for estrus manifestation (Gentry, Walker, \& Gentry, 2016). Therefore, they are less likely to become pregnant because they do not ovulate or ovulate after the viability period of the semen used in TAI (Gentry et al., 2016; Nogueira et al., 2019).

The administration of gonadotropinreleasing hormone $(\mathrm{GnRH})$ in animals that have dominant follicles, but of smaller size, increases the chance of ovulation occurring within the semen viability period, thereby enabling the development of a pregnancy even in animals that are inseminated at a fixed time (Fields et al., 2012). Based on this principle, Rodrigues et al. (2019) evaluated the effects of $\mathrm{GnRH}$ administration in multiparous cows that did not show estrus on the day of TAl and identified an increase in the pregnancy rate.

However, there are differences in the reproductive performance of bovine females (Marques et al., 2015). Thus, we hypothesized that the category may determine an increase in pregnancy in females that do not express estrus and receive $\mathrm{GnRH}$ during TAI. Therefore, the present study aimed to evaluate the effects of nulliparous, primiparous, and multiparous categories on the estrus expression and pregnancy rate of females who do not express estrus but are treated with GnRH during TAl.

\section{Materials and Methods}

\section{Location, animals, and management}

The experiment was conducted on a single commercial beef farm in South Brazil. Bovine females ( $n=531$ ), including nulliparous heifers $(n=144)$, primiparous cows ( $n=132)$, and multiparous cows $(n=255)$ with a body condition score (BCS) ranging from 2.75 to 3.50 (scored on a scale of 1.00 to 5.00 ) were used (Lowman, Scott, \& Somervalle, 1976). Heifers were between 24 and 30 months of age, primiparous cows were between 33 and 39 months of age, and multiparous cows were more than 44 months of age. The cows in the primiparous and multiparous groups were lactating, and had a postpartum period of 3560 days at the beginning of the experiment.

All the animals were kept in a pasture of Brachiaria brizantha cultivar Marandu and supplemented with mineral sources ad libitum. The females from different categories were submitted to a TAl protocol with the same management practices (Figure 1) and inseminated using the semen of a single previously evaluated bull. The groups were compared in terms of the rates of estrus manifestation and pregnancy. 


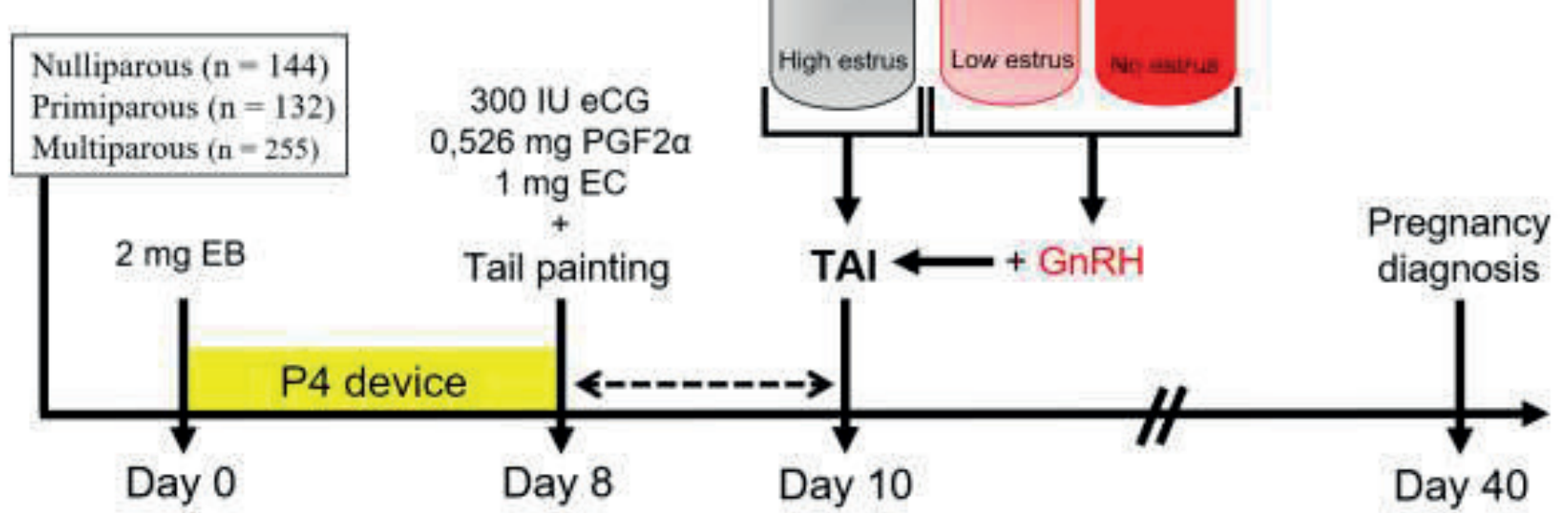

Figure 1. Experimental design and hormonal protocol used for timed artificial insemination (TAI) in heifers and Nelore cows (primiparous and multiparous). The cow's sacrococcygeal region was used to identify estrus in the animals. The sacrococcygeal region was painted on the eighth day of the ovulation induction protocol (D8). On the tenth day of the protocol (D10), the time of $\mathrm{Al}$ of the animals was classified into A - paint completely removed, demonstrating high estrus; B paint partially removed, indicating low estrus; and $\mathrm{C}$ - paint was not removed, indicating no estrus. The $\mathrm{GnRH}$ dose given in females that exhibited no or low estrus is highlighted in red. EB: estradiol benzoate, P4: progesterone, eCG: equine chorionic gonadotropin, PGF2 $\alpha$ : prostaglandin, EC: estradiol cypionate, GnRH: gonadotropin releasing hormone, and DG: pregnancy diagnosis.

Timed artificial insemination and experimental design

The ovulation synchronization protocol (Figure 1) was initiated in all the females on a random day of the estrous cycle (D0) with the application of $2 \mathrm{mg}$ of estradiol benzoate (Syncrogen ${ }^{\circledR}$, GlobalGen Vet Science, Jaboticabal, São Paulo, Brazil), the insertion of an intravaginal device for first use, and impregnation with $1 \mathrm{~g}$ of progesterone (P4; Repro neo ${ }^{\circledR}$, GlobalGen Vet Science, Jaboticabal, São Paulo, Brazil) in primiparous and multiparous cows. For P4 treatment, the group of heifers received a device containing $0.5 \mathrm{~g}$ of P4 (Repro one ${ }^{\circledR}$, GlobalGen Vet Science, Jaboticabal, São Paulo, Brazil). Heifers received a lower dosage of $\mathrm{P} 4$ following the recommendation of Martins et al. (2014). At DO, the BCS was assessed in all the females in the study.

After 8 days (D8), the P4 device was removed and $300 \mathrm{IU}$ of equine chorionic gonadotropin (eCGen ${ }^{\circledR}$, GlobalGen Vet Science, Jaboticabal, São Paulo, Brazil), $0.526 \mathrm{mg}$ of cloprostenol (PGF2 $\alpha$, Induscio ${ }^{\circledR}$, GlobalGen Vet Science, Jaboticabal, São Paulo, Brazil), and estradiol cypionate (0.600 $\mathrm{mg}$ for heifers and $1.000 \mathrm{mg}$ for primiparous and multiparous cows; Cipion ${ }^{\circledR}$, GlobalGen Vet Science, Jaboticabal, São Paulo, Brazil) were applied in all the animals according to Sá et al. $(2014,2015)$. On D8, the sacrococcygeal 
region of all the animals was painted to assess the manifestation of estrus following the methodology described by Nogueira et al. (2019), as shown in Figure 1.

On day 10 (D10; $48 \mathrm{~h}$ after the removal of the intravaginal device), all the females were inseminated. However, the animals that had their tail base paint removed, as shown in image A in Figure 1, were inseminated conventionally, whereas those that had their tail base totally or partially painted, as shown in images $B$ and $C$ in Figure 1, received an injection of $10 \mu \mathrm{g}$ of buserelin acetate (IM, Prorelinn ${ }^{\circledR}$, Boehringer Ingelheim Animal Health, Campinas, São Paulo, Brazil), a synthetic hormone analogous to $\mathrm{GnRH}$. The evaluation for the interpretation of partial paint, total paint, or the absence of paint on the tail was performed as described by Nogueira et al. (2019). Figure 1 highlights the timing of $\mathrm{GnRH}$ administration in females that did not present estrus.

Pregnancy diagnosis was performed in all the females after 30 days of TAI using ultrasound with a $5 \mathrm{MHz}$ transrectal linear transducer (Aloka SSD-500, Aloka Co., Ltd., Tokyo, Japan) and was confirmed by the presence of a viable embryoin the uterus. Both $\mathrm{Al}$ and pregnancy diagnosis were performed by a single trained veterinarian.

\section{Statistical analysis}

The effects of different categories (nulliparous, primiparous, and multiparous) on the rates of estrus expression, conception of females who manifested estrus, and conception of femalesthat received $\mathrm{GnRH}$ were analyzed using a binary logistic regression model, including the effect of the category as a fixed variable and the BCS as a covariate. In the presence of a significant effect, the rates were compared using the chi-square test to rank the categories. For descriptive analysis, the data were presented as percentages (\%). All the statistical analyses were performed using the Minitab ${ }^{\circledR}$ statistical program version 18.1. The level of significance for rejecting $\mathrm{HO}$ (the null hypothesis) was 5\%; therefore, a level of significance of $\leq 0.05$ was considered to indicate an effect of categorical variables and their interactions.

\section{Results and Discussion}

There was no effect $(P>0.1)$ of the BCS on the pregnancy rate in any of the categories assessed. In general, the estrus expression rate was $72.32 \%$ (384/531), which was lower ( $P$ $=0.006)$ in the primiparous females $(61.36 \%$; 81/132) than in the nulliparous (76.39\%; 110/144) and multiparous (75.69\%; 193/255; Figure 2) females. The overall pregnancy rate in this experiment was $74.76 \%$ (397/531), and those in the three categories were similar ( $P=$ 0.98). In general, the pregnancy rate of animals that showed estrus was $82.81 \%$ (318/384), and that of those that did not exhibit estrus and were treated with $\mathrm{GnRH}$ was $53.74 \%$ (79/147). The pregnancy rates did not differ among the animals regardless of whether they showed estrus (Table 1). 
Table 1

Pregnancy rates of Nelore cows of different categories submitted to timed artificial insemination (TAl) with the strategic use of gonadotropin-releasing hormone $(\mathrm{GnRH})$ in females that did not show estrus

\begin{tabular}{cccc}
\hline Category & Pregnancy/Estrus & Pregnancy/GnRH & Total Pregnancy \\
\hline Nulliparous & $84.54 \%(93 / 110)$ & $41.18 \%(14 / 34)$ & $74.30 \%(107 / 144)$ \\
Primiparous & $86.42 \%(70 / 81)$ & $56.86 \%(29 / 51)$ & $75.00 \%(99 / 132)$ \\
Multiparous & $80.31 \%(155 / 193)$ & $58.06 \%(36 / 62)$ & $74.90 \%(191 / 255)$ \\
P-value & 0.39 & 0.24 & 0.98
\end{tabular}

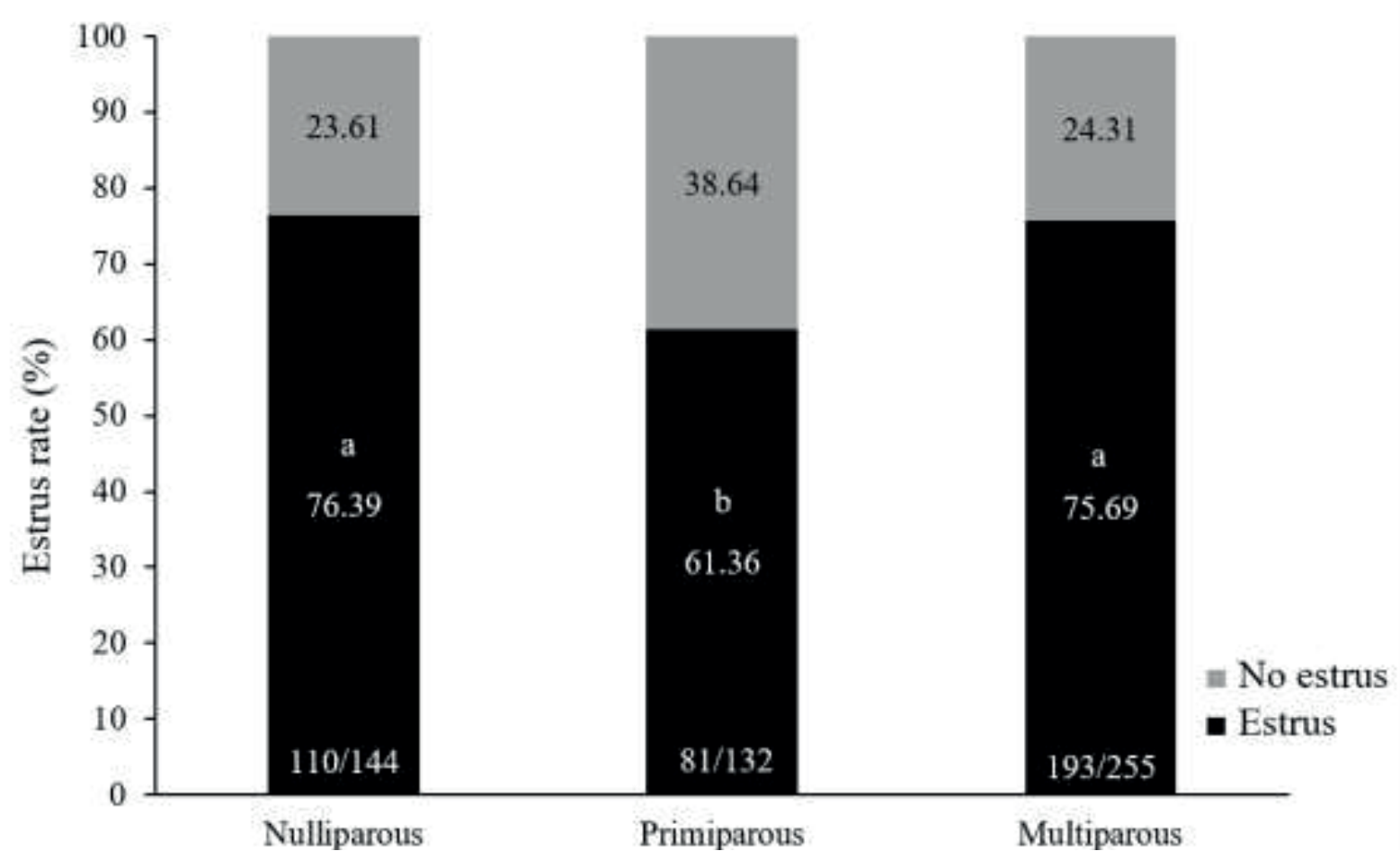

Figure 2. Estrus expression rates in different categories (nulliparous, primiparous, and multiparous) of Nelore females submitted to the ovulation synchronization protocol for timed artificial insemination. The superscripted letters indicate differences $(P=0.006)$ among the categories.

The use of $\mathrm{GnRH}$ to increase the pregnancy rate of females that do not express estrus in TAI has been proven in other studies (Nogueira et al., 2019; Rodrigues et al., 2019). In this study, we investigated whether there is any effect of the female category when employing the same management of $\mathrm{GnRH}$ in TAl. Although the results revealed a lower proportion of primiparous females that expressed estrus in TAl compared with those of nulliparous and multiparous females, the pregnancy rate remained similar between the different categories. 
The primiparous category showed the lowest estrus expression, and similar results were found by Ferraz et al. (2016), who also evaluated the estrus expression in different categories of Nelore females. Primiparous cows are the most metabolically challenged among the Nelore matrixes, especially when raised in a pasture system and receiving only mineral supplementation. In most cases, this challenge is related to the need for primiparous females to have sufficient nutrients for growth and lactation (Cunha, Fernandes, Garcia, \& Gioso, 2013). Under favorable conditions, the primiparous females will make nutrients available for a new pregnancy, thereby demonstrating a lower response in the overall reproductive performance (Oliveira, Bonato, \& Santos, 2011).

In our study, the pregnancy rate was not influenced by the BCS, which was similar to the results reported by Ferraz et al. (2016) who evaluated the effect of the BCS on the reproductive performance in different categories. Although the BCS is an important parameter for determining the metabolic condition of bovine females (Gionbelli et al., 2015), a single assessment at the beginning of the TAl protocol, as was conducted in the present study and in that of Ferraz et al. (2016), does not reliably demonstrate the condition of the cow's energy balance. According to D'Occhio, Baruselli and Campanile (2019), to relate the BSC with the metabolic condition and a better reproductive performance, it is necessary to evaluate the BSC on more occasions, especially at the time of calving, which is difficult to perform in cattle raised in extensive systems. This might have been why the primiparous cows, even though they did not show an adequate BSC at the beginning of the protocol, had a lower estrus expression rate.
In contrast, the primiparous females who showed estrus during TAl had a pregnancy rate similar to that of the nulliparous and multiparous females. This demonstrates that if the primiparous cows show estrus during the synchronization for TAl, they may have a reproductive performance as good as that of the other categories. Regardless of the category, females that showed estrus had pregnancy rates above $80.00 \%$ in the synchronization protocol, which were higher than those found by Nogueira et al. (2019), who reported pregnancy rates of $60.91 \%$ in Nelore multiparous cows that manifested estrus. Regarding the multiparous females in the present study, the total pregnancy rate was $74.90 \%$, which was higher than the $54.01 \%$ reported by Rodrigues et al. (2019), who also administered $\mathrm{GnRH}$ to multiparous females who did not show estrus.

In addition to sanitary and nutritional management, several factors, such as environmental conditions, have a great influence on the reproductive performance of bovine females subjected to TAI (Marques, Morotti, Lorenzetti, Bizarro-Silva, \& Seneda, 2018; Rodrigues et al., 2019). In this context, in multiparous Nelore females submitted to the same type of hormonal protocol used in the present study, Crepaldi, Sales, Girotto, Carvalho and Baruselli (2019) obtained a 68.4\% pregnancy rate, which was not a significant difference, thereby demonstrating that the environmental conditions were very similar to those in the present study. In addition Crepaldi et al. (2019), did not administer GnRH in females that did not express estrus; in comparison with the results of the present study, although the authors found a high pregnancy rate in the multiparous category, it was $6.5 \%$ lower than that in the present study, thereby 
demonstrating that the multiparous category is favorable for the use of $\mathrm{GnRH}$. Primiparous females were also favorable for the use of $\mathrm{GnRH}$ because despite having a lower estrus expression rate, they had the same pregnancy rate as the females in the other categories.

The effect of $\mathrm{GnRH}$ has been proven in a study conducted by Rodrigues et al. (2019), who identified the effects of GnRH administration in 937 multiparous females who did not express estrus on the day of TAI in relation to the control group $(0.90 \% \mathrm{NaCl})$ and observed an increase in the pregnancy rate of $9.77 \%$ with the use of $\mathrm{GnRH}$. However, unlike the study by Rodrigues et al. (2019), this study evaluated the effects of different categories on the use of $\mathrm{GnRH}$ in animals that do not express estrus. Furthermore, primiparous and multiparous females tend to have a lower reproductive performance than nulliparous females (Marques et al., 2015).

The lower reproductive performance in primiparous and multiparous cows is likely related to the fact that they are lactating, which may result in energetic wear, thereby causing a negative energy balance (Astessiano et al., 2014; Marques et al., 2015). Animals with a negative energy balance do not have sufficient luteinizing hormone (LH) peaks to promote ovulation (Cheong et al., 2016; Meteer, Shike, \& Cardoso, 2015). Another factor that can impair ovulation in lactating cows is the sensory interaction between the cow and the calf; according to Dobson, Routly and Smith (2020), this interaction stimulates the secretion of endogenous opioids by the hypothalamus, thereby inhibiting $\mathrm{GnRH}$ secretion and consequently the frequency of LH peaks necessary for ovulation. In addition, the suckling calf has a suction effect, which has been related to the reduction in the amount of intrafollicular receptors for LH (Barreiros et al., 2014; Campos, Marinho, Lunardelli, Morotti, \& Seneda, 2013; Dobson et al., 2020).

However, the use of exogenous $\mathrm{GnRH}$ in lactating animals, even in the presence of calves, causes the release of LH by the pituitary gland and promotes ovulation, thereby resulting in the pregnancy of animals that naturally would not become pregnant when inseminated at a fixed time (D'Occhio et al., 2019). This probably occurred in the group of primiparous and multiparous females, which had the same pregnancy rate as non-lactating nulliparous females.

\section{Conclusions}

Primiparous females showed a lower estrus expression rate in the ovulation synchronization protocol for TAl than nulliparous and multiparous females. However, there was no difference in the pregnancy rate among the three categories of those in estrus and those who did not express estrus but were treated with $\mathrm{GnRH}$.

\section{References}

Astessiano, A. L., Pérez-Clariget, R., Quintans, G., Soca, P., Meikle, A., Crooker, B. A., \& Carriquiry, M. (2014). Metabolic and endocrine profiles and hepatic gene expression in periparturient, grazing primiparous beef cows with different body reserves. Livestock Science, 170(11), 6371. doi: 10.1016/j.livsci.2014.10.008

Barreiros, T. R. R., Blaschi, W., Santos, G. M. G., Morotti, F., Andrade, E. R., Baruselli, P. S., \& Seneda, M. M. (2014). Dynamics of follicular growth and progesterone 
concentrations in cyclic and anestrous suckling Nelore cows (Bos indicus) treated with progesterone, equine chorionic gonadotropin, or temporary calf removal. Theriogenology, 81(5), 651-656. doi: 10. 1016/j.theriogenology.2013.12.008

Baruselli, P. S., Ferreira, R. M., Sá, M. F., Fo., \& Bó, G. A. (2018). Review: using artificial insemination $v$. natural service in beef herds. Animal, 12, 45-52. doi: 10.1017/ S175173111800054X

Campos, J. T., Marinho, L. S. R., Lunardelli, P. A., Morotti, F., \& Seneda, M. M. (2013). Resynchronization of estrous cycle with eCG and temporary calf removal in lactating Bos indicus cows. Theriogenology, 80(6), 619-623. doi: 10. 1016/j.theriogenology.2013.05.029

Cheong, S. H., Sá, O. G., Fo., Absalón-Medina, V. A., Pelton, S. H., Ronald Butler, W. \& Gilbert, R. O. (2016). Metabolic and endocrine differences between dairy cows that do or do not ovulate first postpartum dominant follicles. Biology of Reproduction, 94(1), 1-11. doi: 10.1095/ biolreprod.114.127076

Crepaldi, G. A., Sales, J. N. S., Girotto, R. W., Carvalho, J. G. S., \& Baruselli, P. S. (2019). Effect of induction of ovulation with estradiol benzoate at P4 device removal on ovulation rate and fertility in Bos indicus cows submitted to a TAl protocol. Animal Reproduction Science, 209(6), 106141. doi: 10.1016/j.anireprosci.2019.106141

Cunha, R. R., Fernandes, C.A. C., Garcia, J. A.D., \& Gioso, M. M. (2013). Inseminação artificial em tempo fixo em primíparas Nelore lactantes acíclicas. Arquivo Brasileiro de Medicina Veterinaria e Zootecnia,
65(4), 1041-1048. doi: 10.1590/S010209352013000400015

D'Occhio, M. J., Baruselli, P. S., \& Campanile, G. (2019). Influence of nutrition, body condition, and metabolic status on reproduction infemale beefcattle:areview. Theriogenology, 125(3), 277-284. doi: 10.1016/j.theriogenology.2018.11.010

Dobson, H., Routly, J. E., \& Smith, R. F. (2020). Understanding the trade-off between the environment and fertility in cows and ewes. Animal Reproduction, 17(3), 1-30. doi: 10.1590/1984-3143-AR2020-0017

Ferraz, M. V. C., Jr., Pires, A. V., Biehl, M. V., Santos, M. H., Barroso, J. P. R., Gonçalves, J. R. S.,... Day, M. L. (2016). Comparison of two timed artificial insemination system schemes to synchronize estrus and ovulation in Nellore cattle. Theriogenology, 86(8), 1939-1943. doi: 10.1016/j.theriogenology.2016. 06.012

Ferreira, R. M., Conti, T. L., Gonçalves, R. L., Souto, L. A., Sales, J. N. S., Sá, M. F., Fo.,... Baruselli, P. S. (2018). Synchronization treatments previous to natural breeding anticipate and improve the pregnancy rate of postpartum primiparous beef cows. Theriogenology, 114(10), 206-211. doi: 10.1016/j.theriogenology.2017.11.022

Fields, S. D., Gebhart, K. L., Perry, B. L., Gonda, M. G., Wright, C. L., Bott, R. C., \& Perry, G. A. (2012). Influence of standing estrus before an injection of $\mathrm{GnRH}$ during a beef cattle fixed-time Al protocol on LH release, subsequent concentrations of progesterone, and steriodogenic enzyme expression. Domestic Animal Endocrinology, 42(1), 11-19. doi: 10.10 16/j.domaniend.2011.08.002 
Florindo, T. J., Medeiros Florindo, G. I. B. de, Talamini, E., Costa, J. S. da, \& Ruviaro, C. F. (2017). Carbon footprint and Life Cycle Costing of beef cattle in the Brazilian midwest. Journal of Cleaner Production, 147(28), 119-129. doi: 10.1016/j.jclepro. 2017.01.021

Gentry, G. T., Jr., Walker, R. S., \& Gentry, L. R. (2016). Impacts of incorporation of follicle stimulating hormone into an estrous synchronization protocol for timed artificial insemination of crossbred beef cattle. Animal Reproduction Science, 168(5), 19-25. doi: 10.1016/j. anireprosci.2016.02.021

Gionbelli, M. P., Duarte, M. S., Valadares, S. C. Fo., Detmann, E., Chizzotti, M. L., Rodrigues, F. C.,... Machado, M. G. (2015). Achieving body weight adjustments for feeding status and pregnant or non-pregnant condition in beef cows. PLOS ONE, 10(3), 1-20. doi: 10.1371/journal.pone.0112111

Gouvêa, V. N. de, Colli, M. H. A., Gonçales, A. W., Jr., Motta, J. C. L., Acedo, T. S., Vasconcellos, G. de S. F. M. de,... Baruselli, P. S. (2018). The combination of $\beta$-carotene and vitamins improve the pregnancy rate at first fixed-time artificial insemination in grazing beef cows. Livestock Science, 217(10), 30-36. doi: 10.1016/j.livsci.2018.09.002

Lowman, B. G., Scott, N. A., \& Somervalle, S. $\mathrm{H}$. (1976). Condition scoring of cattle. (Bulletin, 6). Edinburgh: The East of Scotland College of Agriculture.

Marques, M. O., Morotti, F., Lorenzetti, E., Bizarro-Silva, C., \& Seneda, M. M. (2018). Intensified use of TAl and sexed semen on commercial farms. Animal Reproduction,
15(3), 197-203. doi: 10.21451/1984-31 43-AR2018-0070

Marques, M. O., Morotti, F., Silva, C. B. da, Ribeiro, M. Jr., Silva, R. C. P. da, Baruselli, P. S., \& Seneda, M. M. (2015). Influence of category-heifers, primiparous and multiparous lactating cows-in a largescale resynchronization fixed-time artificial insemination program. Journal of Veterinary Science, 16(3), 367-371. doi: 10.4142/jvs.2015.16.3.367

Martins, T., Peres, R. F. G., Rodrigues, A. D. P., Pohler, K. G., Pereira, M. H. C., Day, M. L., \& Vasconcelos, J. L. M. (2014). Effect of progesterone concentrations, follicle diameter, timing of artificial insemination, and ovulatory stimulus on pregnancy rate to synchronized artificial insemination in postpubertal Nellore heifers. Theriogenology, 81(3), 446-453. doi: 10. 1016/j.theriogenology.2013.10.020

Meteer, W. C., Shike, D. W., \& Cardoso, F. C. de. (2015). Prepartum and postpartum nutritional management to optimize fertility in beef cattle. Acta Scientiae Veterinariae, 43(1), 1-18.

Nogueira, E., Silva, M. R., Silva, J. C. B., Abreu, U. P. G., Anache, N. A., Silva, K. C.,... Rodrigues, W. B. (2019). Timed artificial insemination plus heat I: Effect of estrus expression scores on pregnancy of cows subjected to progesterone-estradiol-based protocols. Animal, 13(10), 2305-2312. doi: 10.1017/ S1751731119000442

Oliveira, V. S. A., Bonato, G. L., \& Santos, R. M. dos. (2011). Eficiência reprodutiva de vacas primíparas da raça Nelore. Acta Scientiae Veterinariae, 39(2), 1-4. 
Pfeifer, L. F. M., Castro, N. A., Melo, V. T. O., Neves, P. M. A., Cestaro, J. P., \& Schneider, A. (2015). Timed artificial insemination in blocks: A new alternative to improve fertility in lactating beef cows. Animal Reproduction Science, 163(11), 89-96. doi: 10.1016/j.anireprosci.2015.10.002

Rodrigues, W. B., Silva, A. S., Silva, J. C. B., Anache, N. A., Silva, K. C., Cardoso, C. J. T.,... Nogueira, E. (2019). Timed artificial insemination plus heat II: Gonadorelin injection in cows with low estrus expression scores increased pregnancy in progesterone/estradiol-based protocol. Animal, 13(10), 2313-2318. doi: 10.1017/ S1751731119000454

Rosa, C. O., Bonato, D. V., Souza, A. K., Morotti, F., Francisco, R. C., Basso, A. C.,... Seneda, M. M. (2019). Improvement on the efficiency of doses per conception by using a semen extender in timed artificial insemination. Livestock Science, 221(2019), 77-81. doi: 10.1016/j.livsci.2019.01.014
Sá, M. F., Fo., Marques, M. O., Girotto, R., Santos, F. A., Sala, R. V., Barbuio, J. P., \& Baruselli, P. S. (2014). Resynchronization with unknown pregnancy status using progestin-based timed artificial insemination protocol in beef cattle. Theriogenology, 81(2), 284-290. doi: 10.1016/j.theriogenology. 2013.09.027

Sá, M. F., Fo., Nasser, L. F. T., Penteado, L., Prestes, R., Marques, M. O., Freitas, B. G.,... Baruselli, P. S. (2015). Impact of progesterone and estradiol treatment before the onset of the breeding period on reproductive performance of Bos indicus beef heifers. Animal Reproduction Science, 160(9), 30-39. doi: 10.1016/j. anireprosci.2015.06.024 
